\title{
ANALISIS TINGKAT PENGEMBALIAN SAHAM PADA INDUSTRI DASAR KIMIA SUBSEKTOR LOGAM
}

\author{
Gelar Rialdi Pratama ${ }^{1}$, Erry Sunarya ${ }^{2}$, Acep Samsudin ${ }^{3}$ \\ Universitas Muhammadiyah Sukabumi ${ }^{1,2,3}$ \\ gelarrialdi@gmail.com ${ }^{1}$
}

\begin{abstract}
ABSTRAK
Penelitian ini bertujuan untuk mengetahui seberapa besar pengembalian saham yang terdapat pada PT. Lion Metal Work dengan metode Earning Per Share (EPS), dan juga ingin mengetahui tingkat pengembalian hutang pada PT. Lion Metal Work dengan metode Debt To Equity Ratio. Hasil penelitian ini menyatakan bahwa nilai Earning Per Share pada tahun 2015-2016 mengalami peningkatan diatas standar rata-rata industri, dan pada tahun 2017 perusahaan mengalami penurunan dibawah standar rata-rata industri, sedangkan hasil dari Debt to Equity Ratio ini menyatakan bahwa perusahaan pada tahun 2015-2017 mengalami peningkatan akan tetapi nilai Debt To Equity Ratio kurang dari standar rata-rata industry. Masalah perusahaan berada pada kinerja perusahaan yang sedang mengalami penurunan serta nilai laba yang terus menurun dan total hutang yang terus bertambah. Simpulan, berdasarkan hasil dan analisa data penelitian, pengembalian saham perusahaan kurang baik, begitu juga dengan pengembalian hutang yang masuk kategori kecil atau kurang baik karena terjadi kenaikan hutang dari tahun ketahun sementara tingkat pengembalian hutang perusahaan yang kecil.
\end{abstract}

Kata Kunci: Earning Per Share, tingkat pengembalian Saham, Debt To Equity Ratio.

\section{ABSTRACT}

This study aims to determine how much return on shares contained in PT. Lion Metal Work with the Earning Per Share (EPS) method, and also wants to know the rate of return on debt at PT. Lion Metal Work with the Debt To Equity Ratio method. The results of this study state that the value of Earning Per Share in 2015-2016 has increased above the industry average standard, and in 2017 the company has decreased below the industry average standard, while the results of the Debt to Equity Ratio state that the company in 2015-2017 has increased but the value of the Debt To Equity Ratio is less than the industry average standard. The company's problems are in the performance of companies that are experiencing a decline and the value of profits continues to decline and the total debt continues to grow. Conclusions, based on the results and analysis of research data, the return of company shares is not good, as well as the return of debts that are categorized as small or not good because of an increase in debt from year to year while the rate of return on corporate debt is small.

Keywords: Earning Per Share, stock returns, Debt To Equity Ratio. 


\section{PENDAHULUAN}

Salah satu cara mengkoordinasi kegiatan dalam pencapaian suatu kesejahteraan investor dengan mendapatkan pengembalian laba yang baik dan juga cepat adalah untuk mendapatkan suntikan dana dari para investor yang akan menanamkan modal pada sektor pasar modal.

Pasar modal merupakan bentuk dari pasar yang berisi tentang keuangan. Dimana bentuk pelakunya adalah orang-orang yang mempunyai kelebihan uang dan melakukan investasi pada perusahaan. Begitupun yang dikemukakan oleh Irham Fahmi (2014) "pasar modal adalah sebuah pasar tempat dana-dana modal seperti equitas dan utang diperdagangkan".

Salah satu kelebihan pasar modal adalah penyediaan modal jangka panjang dan tanpa batas selain itu perusahaan yang tidak mempunyai dana bisa menawarkan surat berhaga atau surat hutang untuk dijual kepada pihak lain yang ingin membeli surat tersebut selain itu hal yang menarik dari saham adalah turun naiknya harga sehingga banyak orang yang ingin mencoba melakukan investasi pada perusahaan.

Memprediksi return saham banyak alat ukur yang bisa digunakan untuk mendapatkan tingkat keuntungan yang maksimal investor harus mengetahui informasi prediksi harga yang sudah bisa dipakai, termasuk kondisi keuangan perusahaan dimasa yang akan datang. Adapun cara atau alat yang bisa memprediksi pengembalian saham dengan menggunakan analisis rasio keuangan. Rasio keuangan adalah bersumber dari laporan keuangan, pada rasio keuangan aktifitas-aktifitas tentang keuangan harus diperhatikan terutama pada saham, didalam tiap perusahaan yang go public harus melampirkan rasio keuangan sesuai dengan ketentuan Otoritas Jasa Keuangan (OJK) Nomor KEP-15/PM/1996 tanggal 17 Januari 1996.

Rasio keuangan yang dapat mengukur return saham antara lain Earning Per Share (EPS), Debt to Equity Ratio (DER). Earning Per Share (EPS) atau laba perlembar saham merupakan rasio untuk mengukur keberhasilan manajemen dalam mencapai keuntungan bagi pemegang saham. Dalam hal ini para investor harus lebih teliti dalam menghitung Earning Per Share, perhitungan ini yang akan memprediksi apakah investor akan untung atau malah sebaliknya karena pada perhitungan Earning Per Share investor bisa melihat perhitungan laba pada saham dan laba yang biasa beredar, jadi para investor akan tahu apakah investasinya sendiri memiliki keuntungan 
atau mengalami penurunan dalam pertahunnya. Harga saham akan turun jika volume penjualan harga perlembar saham juga mengalami penurunan, itu semuanya bisa terjadi apabila banyak dari negara asing ataupun dari negara tersebut yang menjual saham.

Debt To Equity Ratio (DER) adalah untuk mengetahui sejauh mana kemampuan perusahaan dalam memenuhi kewajiban dengan menggunakan ekuitas perusahaan. Dari hasil pengukuran, bagi bank apabila rasionya tinggi, artinya pendanaan dengan utang semakin banyak, maka semakin sulit bagi perusahaan untuk memperoleh tambahan pinjaman. Dalam hal ini para investor atau para kreditor enggan memberikan tambahan modal dikarenakan perusahaan banyak mempunyai utang dan beberapa pendanaan perusahaan dibiayai dengan utang maka dari itu para investor atau kreditor khawatir perusahaan tidak mampu menutupi utang-utangnya dengan aktiva perusahaan tersebut, tetapi bagi perusahaan yang sudah go public apabila rasionya tinggi itu semakin bagus.

PT. Lion Metal Work Tbk terdaftar pada BEI dengan kode saham LION yang bergerak pada bidang pembuatan alat kantor dari baja, peralatan gudang, bahan bangunan dan peralatan rumah sakit. Pada saat ini berupaya memperbaiki kinerjanya, melakukan efisiensi, dan peningkatan produktivitas dari tahun pertahun. Berikut adalah grafik yang menggambarkan kondisi harga saham PT. Lion Metal Work Tbk yang mengalami penurunan pada tiap tahunnya.

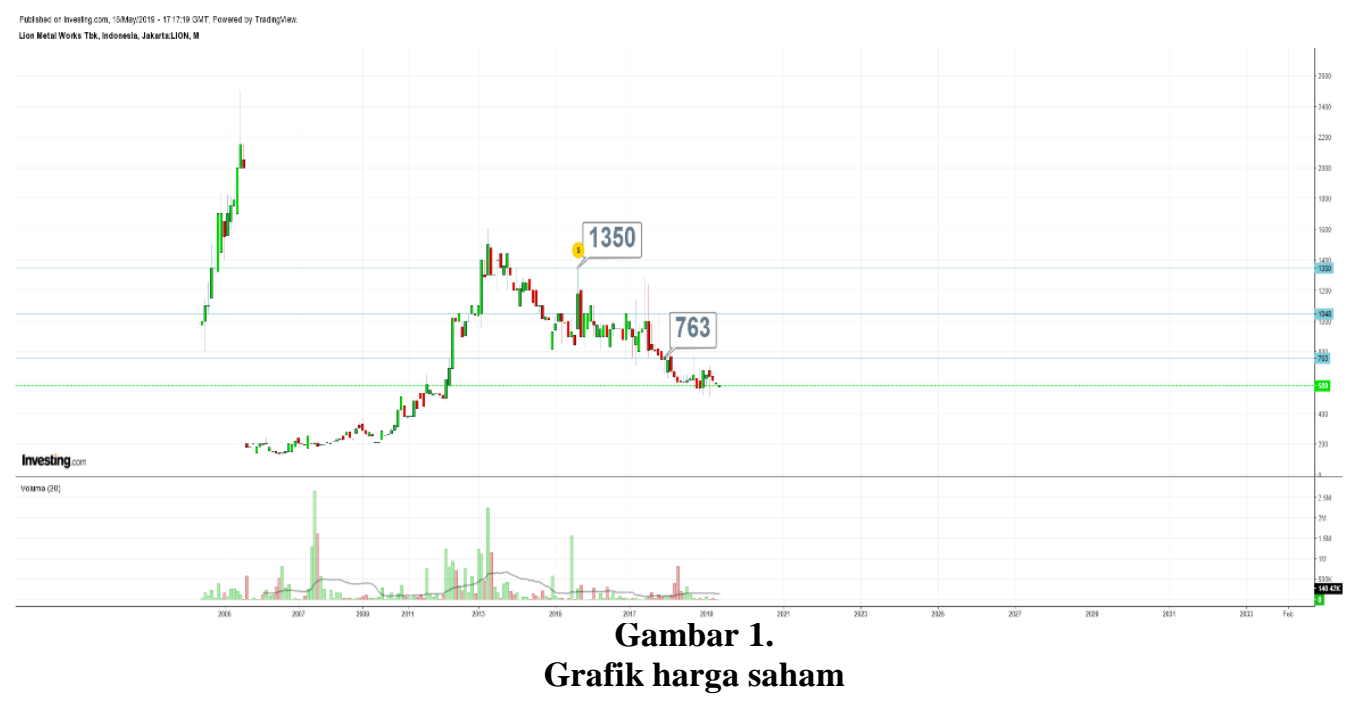

Dalam grafik ini bisa dilihat bahwa harga saham pada PT. Lion Metal Work Tbk mengalami penurunan yang cukup besar, harga perlembar saham PT. Lion Metal Work dari Rp.1.350 menjadi Rp.763 dalam hal ini ada beberapa yang menjadi permasalahan 
penyebab terjadinya penurunan saham pada PT. Lion Metal Work yaitu menurunnya kinerja perusahaan serta pengembalian saham perusahaan yang turun sangat signifikan dan rendahnya tingkat pengembalian hutang, sehingga para pemegang saham mengalami kerugian.

Berdasarkan latar belakang dan data diatas, maka peneliti mengambil judul “Analisis Tingkat Pengembalian Saham Pada Industri Dasar dan Kimia Subsektor logam (Studi Kasus PT. Lion Metal Work Tbk)". Tujuan penelitian ini adalah untuk mengetahui seberapa besar pengembalian saham yang terdapat pada PT. Lion Metal Work dengan metode Earning Per Share (EPS), dan juga ingin mengetahui tingkat pengembalian hutang pada PT. Lion Metal Work dengan metode Debt To Equity Ratio.

\section{KAJIAN TEORI}

\section{Manajemen Keuangan}

Manajemen keuangan adalah peranan penting pada perkembangan sebuah perusahaan. Dalam penerapannya, manajemen keuangan tidak dapat berdiri sendiri. Manajemen keuangan selalu berkaitan erat dengan berbagai disiplin ilmu yang lain seperti akuntansi, ilmu ekonomi, manajemen pemasaran, manajemen produksi, metode kuantitatif, dan manajemen sumber daya manusia. Menurut Kasmir (2010) "Manajemen keuangan adalah segala aktivitas yang berhubungan dengan perolehan, pendanaan, dan pengelolaan aktiva dengan beberapa tujuan menyeluruh".

\section{Pasar Modal}

Pasar modal adalah sebuah pasar yang menjual surat-surat berharga untuk jangka Panjang, pasar modal juga menjadi sumber pendanaan bagi perusahaan ataupun pemerintah. Menurut Widoatmodjo (2012) "Pengertian pasar modal adalah pasar abstrak, dimana yang diperjual belikan adalah dana-dana jangka panjang, yaitu dan yang keterikatannya dalam investasi lebih dari satu tahun".

\section{Pengertian Saham}

Menurut Irham Fahmi (2017) saham adalah saham yang berasal dari perusahaan lain, yang dibeli oleh pihak manajemen perusahaan dan selanjutnya sewaktu-waktu bisa dijual kembali jika membutuhkan dana. 


\section{Return Saham}

Dalam sebuah investasi tentunya para investor ingin mengalami keuntungan, return saham adalah keuntungan yang didapat dalam melakukan investasi. Menurut Legiman (2015) dalam Rendi (2016) berpendapat bahwa Return saham merupakan hasil yang diperoleh dari investasi. Harapan untuk memperoleh return juga terjadi dalam asset financial. Suatu asset financial menunjukkan kesediaan investor menyediakan sejumlah dana pada saat ini untuk memperoleh sebuah aliran dana pada masa yang akan datang sebagai kompensasi atas faktor waktu selama dana ditanamkan dan risiko yang ditanggung. Dengan demikian para investor sedang mempertaruhkan suatu nilai sekarang untuk sebuah nilai yang diharapkan pada masa mendatang. Dalam konteks manajemen investasi, return atau tingkat keuntungan merupakan imbalan yang diperoleh dari investasi.

\section{Pengertian Laporan Keuangan}

Irham Fahmi (2017) menyatakan bahwa "Definisi laporan keuangan merupakan suatu informasi yang menggambarkan kondisi keuangan suatu perusahaan, dan lebih jauh informasi tersebut dapat dijadikan sebagai gambaran kinerja keuangan perusahaan tersebut".

\section{Rasio Pasar}

Rasio nilai pasar yaitu rasio yang mengagambarkan kondisi yang terjadi di pasar. Rasio ini meampu memberi pemahaman bagi pihak manajemen perusahaan terhadap kondisi penerapan yang akan dilaksanakan dalam dampaknya pada masa yang akan datang.

\section{Price Earning ratio}

Bagi para investor semakin tinggi price earning ratio maka pertumbuhan laba yang diharapkan juga akan mengalami kenaikan. Dengan begitu price earning ratio (ratio harga terhadap laba) adalah perbandingan antara market price per share (harga pasar per lembar saham) dengan earning per share (laba per lembar saham). Adapun menurut Van Horne dan Wachowicz dalam Irham Fahmi (2017) "harga pasar per saham dari saham biasa perusahaan dibagi dengan 12 tingkat pendapatan per saham terbaru”. Sedangkan menurut Sudana (2011) menyatakan bahwa Price Earning ratio adalah rasio yang merupakan indikator bagi prospek pendapatan perusahaan dimasa mendatang yang 
dihitung dengan cara membagi harga saham perlembar saham biasa pada tanggal tertentu dengan laba per saham tahunan".

\section{Earning Per Share}

Menurut Darsono dan Ashari (2005) Investor biasanya lebih tertarik dengan ukuran profitabilitas dengan menggunakan dasar saham yang dimiliki. Alat analisis yang dipakai untuk melihat keuntungan dengan dasar saham saham adalah earning per share yang dicari dengan laba bersih dibagi saham yang beredar.

Menurut Irham Fahmi (2017) bahwa "earning per share atau pendapatan per lembar saham adalah bentuk pemberian keuntungan yang diberikan kepada para pemegang saham dari setiap lembar saham yang dimiliki”.

Hal ini sesuai dengan pendapat Kasmir (2015) bahwa "earning per share adalah rasio laba perlembar saham atau disebut juga rasio nilai buku merupakan rasio untuk mengukur keberhasilan manajemen dalam mencapai keuntungan bagi para pemegang saham".

Dari pendapat para ahli diatas dapat disimpulkan bahwa earning per share adalah laba perlembar saham yang dimana rasio ini mengukur untuk keuntungan para investor dan sarana untuk melihat pembelian pada saham perusahaan.

\section{Rasio Leverage}

Menurut Samryn (2012) menyatakan bahwa rasio leverage atau biasa disebut rasio hutang terdiri dari; Rasio kewajiban terhadap aktiva, Rasio kewajiban terhadap ekuitas, Rasio kewajiban jangka panjang terhadap struktur modal dan Times interest earned.

Sedangkan menurut Dwi Prastowo (88:2014) bahwa Posisi kreditor jangka panjang berbeda dibanding kreditorianak jangka panjang sangat menaruh perhatian, baik pada kemampu memenuhi kewajiban jangka pendek, yaitu kemampuan membayar bungam jangka panjang, yaitu kemampuan membayar pokok pinjaman. Kemudia Fred Weston di kutip dari Kasmir (150:2008) menyatakan bahwa Rasio solvabilitas atau leverage merupakan rasio yang di gunakan dalam mengukur sejauh mana aktiva perusahaan di biayai dengan hutang dan mengukur kemampuan perusahaan untuk 
membayar seluruh kewajibannya, baik itu periodenya jangka pendek atau jangka panajang jika perusahaan dilikuidasi (dibubarkan).

\section{Debt to Total Asset atau Debt Ratio}

Menurut Irham Fahmi (2017) "Dimana rasio ini disebut juga sebagai rasio yang melihat perbandingan utang perusahaan, yaitu diperoleh dari perbandingan total utang dibagi total asset".

\section{Debt to Equity Ratio}

Menurut Kasmir (2015:157) menyatakan bahwa Debt to equity ratio merupakan rasio yang digunakan untuk menilai utang dengan ekuitas. Rasio ini dicari dengan membandingkan antara seluruh hutang, termasuk utang lancar dengan seluruh ekuitas. Rasio ini berguna untuk mengetahui jumlah dana yang disediakan peminjaman dengan pemilik perusahaan. Dengan kata lain, rasio ini berfungsi untuk mengetahui setiap rupiah modal sendiri yang dijadikan untuk jaminan utang.

\section{METODE PENELITIAN}

Metode penelitian yang digunakan oleh peneliti adalah metode deskriptif dengan pendekatan kuantitatif, menurut Arikunto (2014) "Penelitian kuantitatif banyak dituntut menggunakan angka, mulai dari pengumpulan data, penafsiran berupa data tersebut, serta penampilan dari hasilnya".

Menurut Sugiyono (2014), definisi metode deskriptif adalah suatu rumusan masalah yang berkenaan dengan pertanyaan terhadap keberadaan variabel mandiri, baik hanya satu variabel atau lebih (variabel mandiri adalah variabel yang berdiri sendiri, buakn variabel independen, karena kalau variabel independen selalu dipasangkan dengan variabel dependen).

Penelitian ini menggunakan data sekunder berupa rilisan saham dan catatan keuangan dari Bursa Efek Indonesia dari perusahaan PT. Lion Metal Work dengan teknik Analisis Data:

$$
E P S \frac{\text { EAT }}{\mathrm{Jsb}}
$$

EPS = Earning Per Share

EAT = Earning After Tax atau pendapatan setelah pajak

$\mathrm{Jsb}=$ Jumlah saham yang beredar 


$$
D E R \frac{\text { Total Hutang }}{\text { Ekuitas }}
$$

\section{HASIL PENELITIAN}

\section{Perbandingan Standar Rata-Rata Industri}

Perhitungan rata-rata industri ini dapat digunakan untuk membandingkan tingkat pengembalian saham dan tingkat pengembalian hutang pada antar perusahaan yang sejenis. Berikut ini adalah hasil dari rata-rata data Earning Per Share dan Debt To Equity pada perusahaan industri dasar dan kimia subsektor logam yang terdaftar pada Bursa Efek Indonesia.

Tabel 1.

Standar Rata-Rata Industri Earning Per Share Tahun 2015

\begin{tabular}{lc}
\hline \multicolumn{1}{c}{ PERUSAHAAN } & Earning Per Share \\
\hline PT. Alaska Industindo Tbk & 11,62 \\
\hline PT. Beton Jaya Manunggal Tbk & 8,78 \\
\hline PT. Citra Turbindo Tbk & 0,01 \\
\hline PT. Gunawan Dianjaya Steel Tbk & 6,73 \\
\hline PT. Indal Aluminium Industry Tbk & 90,33 \\
\hline PT. Jakarta Kyoel Steel Tbk & 153,97 \\
\hline PT. Jaya Paris Steel Tbk & 6,00 \\
\hline PT. Lion Mesh Prima Tbk & 20,00 \\
\hline PT. Lion Metal Work Tbk. & 88,00 \\
\hline Standar Rata-Rata Industri Earning Per Share 2015 & $\mathbf{4 2 . 8 2}$ \\
\hline Sumber: Data diolah oleh 2019
\end{tabular}

Tabel 2.

Standar Rata-Rata Industri Earning Per Share Tahun 2016

\section{PERUSAHAAN}

\begin{tabular}{lc}
\hline PT. Alaska Industindo Tbk & 1,13 \\
\hline PT. Beton Jaya Manunggal Tbk & 8,30 \\
\hline PT. Citra Turbindo Tbk & 0,0011 \\
\hline PT. Gunawan Dianjaya Steel Tbk & 3,87 \\
\hline PT. Indal Aluminium Industry Tbk & 112,23 \\
\hline PT. Jakarta Kyoel Steel Tbk & 19,30 \\
\hline PT. Jaya Paris Steel Tbk & 25,69 \\
\hline PT. Lion Mesh Prima Tbk & 65,00 \\
\hline
\end{tabular}




\begin{tabular}{lc}
\hline PT. Lion Metal Work Tbk. & 81,00 \\
\hline Standar Rata-Rata Industri Earning Per Share 2016 & $\mathbf{3 5 , 1 6}$ \\
\hline Sumber: Data diolah oleh 2019 &
\end{tabular}

Tabel 3.

Standar Rata-Rata Industri Earning Per Share Tahun 2017

\begin{tabular}{lc}
\hline \multicolumn{1}{c}{ PERUSAHAAN } & Earning Per Share \\
\hline PT. Alaska Industindo Tbk & 30,38 \\
\hline PT. Beton Jaya Manunggal Tbk & 15,79 \\
\hline PT. Citra Turbindo Tbk & 0,0151 \\
\hline PT. Gunawan Dianjaya Steel Tbk & 1,25 \\
\hline PT. Indal Aluminium Industry Tbk & 61,00 \\
\hline PT. Jakarta Kyoel Steel Tbk & 26,16 \\
\hline PT. Jaya Paris Steel Tbk & 19,86 \\
\hline PT. Lion Mesh Prima Tbk & 135,00 \\
\hline PT. Lion Metal Work Tbk. & 18,00 \\
\hline Standar Rata-Rata Industri Earning Per Share $\mathbf{2 0 1 6}$ & $\mathbf{3 4 , 1 6}$ \\
\hline Sumber: Data diolah 2019 &
\end{tabular}

Sumber: Data diolah 2019

Tabel 4.

Standar Rata-Rata Industri Debt To Equity Ratio Tahun 2015

\begin{tabular}{lc}
\multicolumn{1}{c}{ PERUSAHAAN } & $\begin{array}{c}\text { Debt To Equity } \\
\text { Ratio }\end{array}$ \\
\hline PT. Alaska Industindo Tbk & 1,33 \\
\hline PT. Beton Jaya Manunggal Tbk & 0,22 \\
\hline PT. Citra Turbindo Tbk & 0,76 \\
\hline PT. Gunawan Dianjaya Steel Tbk & 0,47 \\
\hline PT. Indal Aluminium Industry Tbk & 4,54 \\
\hline PT. Jakarta Kyoel Steel Tbk & 2,66 \\
\hline PT. Jaya Paris Steel Tbk & 0,09 \\
\hline PT. Lion Mesh Prima Tbk & 0,18 \\
\hline PT. Lion Metal Work Tbk. & 0,40 \\
\hline Standar Rata-Rata Industri Debt To Equity Ratio $\mathbf{2 0 1 6}$ & $\mathbf{1 , 1 8}$ \\
\hline
\end{tabular}

Sumber: Data diolah 2019

Tabel 5.

Standar Rata-Rata Industri Debt To Equity Ratio Tahun 2016

\begin{tabular}{lc}
\multicolumn{1}{c}{ PERUSAHAAN } & $\begin{array}{c}\text { Debt To Equity } \\
\text { Ratio }\end{array}$ \\
\hline PT. Alaska Industindo Tbk & 1,2 \\
\hline PT. Beton Jaya Manunggal Tbk & 1,33 \\
\hline PT. Citra Turbindo Tbk & 0,35 \\
\hline
\end{tabular}




\begin{tabular}{ll}
\hline PT. Gunawan Dianjaya Steel Tbk & 0,51 \\
\hline PT. Indal Aluminium Industry Tbk & 4,18 \\
\hline PT. Jakarta Kyoel Steel Tbk & 1,61 \\
\hline PT. Jaya Paris Steel Tbk & 0,13 \\
\hline PT. Lion Mesh Prima Tbk & 0,38 \\
\hline PT. Lion Metal Work Tbk. & 0,45 \\
\hline Standar Rata-Rata Industri Debt To Equity Ratio $\mathbf{2 0 1 6}$ & $\mathbf{1 , 0 0}$ \\
\hline
\end{tabular}

Sumber: Data diolah 2019

Tabel 6.

Standar Rata-Rata Industri Debt To Equity Ratio Tahun 2017

\begin{tabular}{lc}
\multicolumn{1}{c}{ PERUSAHAAN } & $\begin{array}{c}\text { Debt To Equity } \\
\text { Ratio }\end{array}$ \\
\hline PT. Alaska Industindo Tbk & 2.8 \\
\hline PT. Beton Jaya Manunggal Tbk & 0,18 \\
\hline PT. Citra Turbindo Tbk & 0,41 \\
\hline PT. Gunawan Dianjaya Steel Tbk & 0,52 \\
\hline PT. Indal Aluminium Industry Tbk & 3,37 \\
\hline PT. Jakarta Kyoel Steel Tbk & 1,56 \\
\hline PT. Jaya Paris Steel Tbk & 0,22 \\
\hline PT. Lion Mesh Prima Tbk & 0,24 \\
\hline PT. Lion Metal Work Tbk. & 0,50 \\
\hline Standar Rata-Rata Industri Debt To Equity Ratio $\mathbf{2 0 1 7}$ & $\mathbf{1 , 1 8}$ \\
\hline Sumber: Datadiolah 2019
\end{tabular}

Sumber: Data diolah 2019

\section{PEMBAHASAN}

\section{Analisis Tingkat Pengembalian Saham Dengan Menggunakan Earning Per Share dan Debt To Equity Ratio}

Penelitian ini menggunakan laporan keuangan dari selama tiga tahun yaitu dari tahun 2015 sampai dengan tahun 2017 untuk mengetahui tingkat pengembalian saham dan tingkat pengembalian hutang.

\section{Earning Per Share}

Earning Per Share adalah laba lembar saham pada sebuah perusahaan yang membuka sebuah investasi apabila rasionya tinggi maka kesejahteraan investor meningkat sedangkan apabila rasionya rendah maka sebuah perusahaan belum bisa memuaskan investor. Berikut cara perhitungan mencari Earning Per Share:

Cara perhitungan Earning Per Share PT. Lion Metal Work 2015

Earning Per Share = pendapatan setelah pajak / Jumlah saham yang beredar

$$
E P S=\frac{46.018 .637 .487}{520.160 .000}=88.47
$$


Berdasarkan hasil perhitungan data dari laporan keuangan dan standar rata- rata industri subsektor logam bahwa nilai Earning Per Share PT. Lion Metal Work Tbk. Mengalami peningkatan pada tahun 2015 sebesar 45.65 hal ini menunjukan tingkat pengembalian saham PT. Lion Metal Work diatas rata-rata yakni 42,82 dilihat dari Standar rata-rata industri subsektor logam, atau bisa dikatakan pengembalian sahamnya besar.

Cara perhitungan Earning Per Share PT. Lion Metal Work Tb 2016

$$
E P S=\frac{42.345 .417 .055}{520.160 .000}=81.40
$$

Berdasarkan hasil perhitungan data dari laporan keuangan dan standar rata- rata industri subsektor logam bahwa nilai Earning Per Share PT. Lion Metal Work Tbk. Mengalami peningkatan pada tahun 2016 sebesar 46.24 hal ini menunjukan tingkat pengembalian saham PT. Lion Metal Work diatas rata-rata yakni 35,16 dilihat dari Standar rata-rata industri subsektor logam, atau bisa dikatakan pengembalian sahamnya besar.

Cara perhitungan Earning Per Share PT. Lion Metal Work Tbk 2017

$$
E P S=\frac{9.282 .943 .009}{520.160 .000}=17.84
$$

Berdasarkan hasil perhitungan data dari laporan keuangan dan standar rata- rata industri subsektor logam bahwa nilai Earning Per Share PT. Lion Metal Work Tbk. Mengalami penurunan pada tahun 2017 sebesar 16.32 dikarenakan EAT PT. Lion Metal work Tbk mengalami penurunan dari tahun sebelumnya

Tabel 7.

Rekapitulasi hasil perhitungan earning per share PT. Lion Metal Work Tbk. Periode 2015-2017

\begin{tabular}{ccccc}
\hline Tahun & $\begin{array}{c}\text { Earning After } \\
\text { Tax }(\mathbf{E})\end{array}$ & $\begin{array}{c}\text { Jumlah Saham } \\
\text { Yang Beredar }(\mathbf{J})\end{array}$ & $\begin{array}{c}\text { Hasil } \\
(\mathbf{E} / \mathbf{J})\end{array}$ & $\begin{array}{c}\text { Standar Rata- } \\
\text { Rata Industri }\end{array}$ \\
\hline $\mathbf{2 0 1 5}$ & $\mathbf{4 6 . 0 1 8 . 6 3 7 . 4 8 7}$ & $\mathbf{5 2 0 . 1 6 0 . 0 0 0}$ & $\mathbf{8 8 . 4 7}$ & $\mathbf{4 2 . 8 2}$ \\
\hline $\mathbf{2 0 1 6}$ & $\mathbf{4 2 . 3 4 5 . 4 1 7 . 0 5 5}$ & $\mathbf{5 2 0 . 1 6 0 . 0 0 0}$ & $\mathbf{8 1 . 4 0}$ & $\mathbf{3 5 . 1 6}$ \\
\hline $\mathbf{2 0 1 7}$ & $\mathbf{9 . 2 8 2 . 9 4 3 . 0 0 9}$ & $\mathbf{5 2 0 . 1 6 0 . 0 0 0}$ & $\mathbf{1 7 . 8 4}$ & $\mathbf{3 4 . 1 6}$ \\
\hline
\end{tabular}




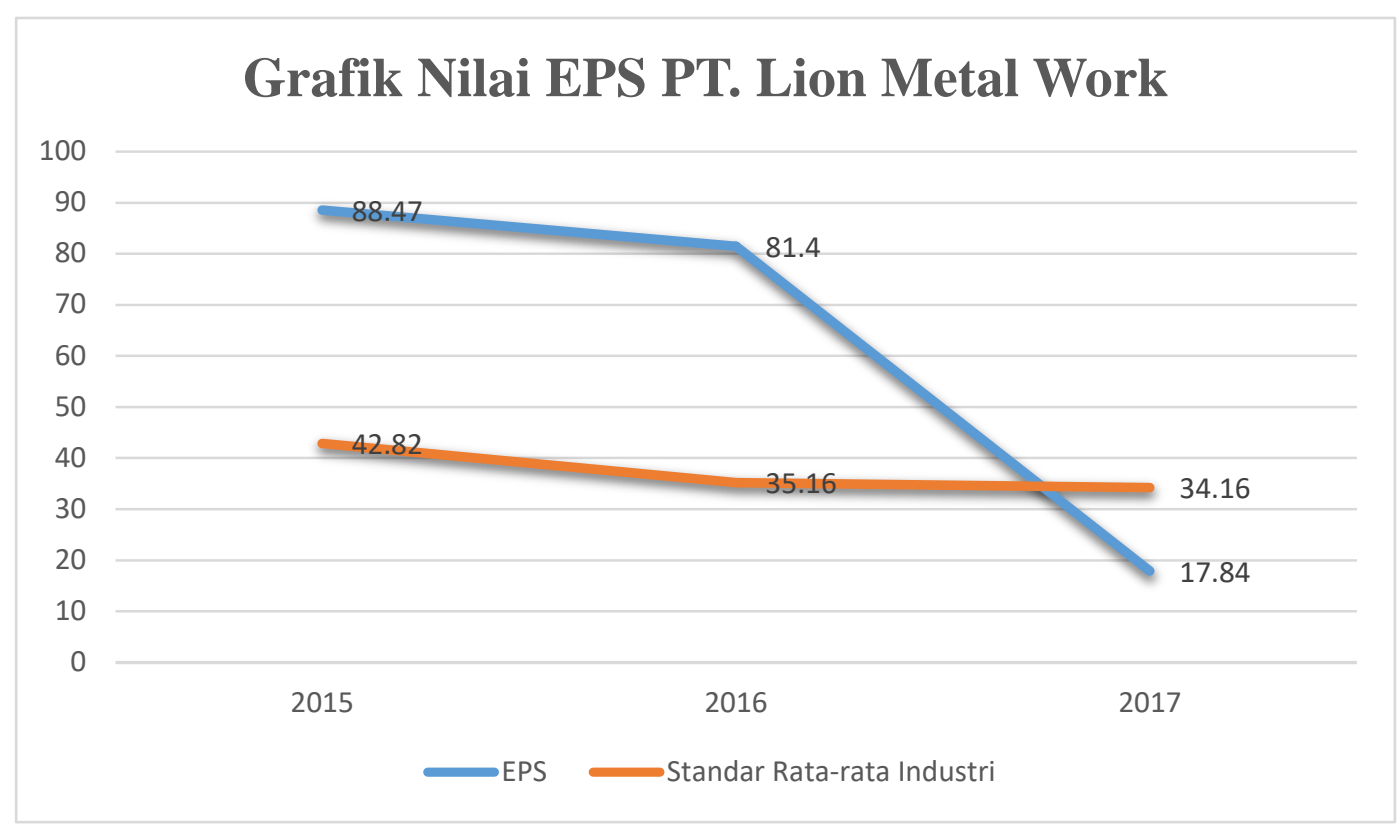

Gambar 2.

Grafik nilai EPS PT. Lion Metal Work

Berdasarkan perhitungan tabel 7 diatas, perusahaan PT. Lion Metal Work mengalami penurunan dari tahun ketahun khususnya pada tahun 2017 yang dimana PT. Lion Metal Work mengalami penurunan yang drastis sehingga para investor mengalami kerugian cukup besar, penurunan terjadi karena kinerja perusahaan saat ini sedang menurun serta pengembalian saham perusahaan yang turun sangat signifikan dan rendahnya tingkat pengembalian hutang.

\section{Debt To Equity Ratio}

Debt To Equity Ratio adalah sebuah rasio untuk menilai sebuah hutang perusahaan dan layak atau tidak untuk diberi investasi apabila rasionya tinggi untuk perusahan bank maka tingkat pengembalian hutangnya rendah dan sebaliknya apabila nilai rasionya besar untuk perusahaan yang go public maka tingkat pengembalian hutangnya besar. Berikut adalah cara untuk mencari Debt To Equity Ratio:

Cara perhitungan Debt To Equity Ratio PT. Lion Metal Work Tbk 2015

$$
D E R=\frac{184.730 .654 .202}{454.599 .496 .171}=0.40
$$


Berdasarkan hasil perhitungan data dari laporan keuangan dan standar rata- rata industri subsektor logam bahwa nilai Debt To Equity Ratio PT. Lion Metal Work Tbk. Mengalami penurunan pada tahun 2015 sebesar 0.78 hal ini menunjukan tingkat pengembalian hutang PT. Lion Metal Work dibawah rata-rata yakni 1.18 dilihat dari Standar rata-rata industri subsektor logam, atau bisa dikatakan pengembalian hutangnya kecil.

Cara perhitungan Debt To Equity Ratio PT. Lion Metal Work Tbk 2016

$$
D E R=\frac{215.209 .902 .816}{470.603 .093 .171}=0.45
$$

Berdasarkan hasil perhitungan data dari laporan keuangan dan standar rata- rata industri subsektor logam bahwa nilai Debt To Equity Ratio PT. Lion Metal Work Tbk. Mengalami penurunan pada tahun 2016 sebesar 0.55, hal ini menunjukan tingkat pengembalian hutang PT. Lion Metal Work dibawah rata—rata yakni 1.00 dilihat dari Standar rata-rata industri subsektor logam, atau bisa dikatakan pengembalian hutangnya kecil. Cara perhitungan Debt To Equity Ratio PT. Lion Metal Work Tbk 2017

$$
D E R=\frac{229.630 .859 .719}{452.307 .088 .017}=0.50
$$

Berdasarkan hasil perhitungan data dari laporan keuangan dan standar rata- rata industri subsektor logam bahwa nilai Debt To Equity Ratio PT. Lion Metal Work Tbk. Mengalami penurunan pada tahun 2017 sebesar 0.58 hal ini menunjukan tingkat pengembalian hutang PT. Lion Metal Work Tbk. Ddibawah rata_—rata yakni 1.08 ini dikarenakan total hutang PT. Lion Metal Work Tbk mengalami kenaikan dari tahun sebelumnya begitupun dengan total Ekuitas juga mengalami penurunan hal tersebut menunjukan bahwa pengembalian hutang PT. Lion Metal Work Tbk. Bisa dikatakan kurang baik.

Tabel 8.

Rekapitulasi hasil perhitungan nilai deb PT. Lion Metal Work Tbk.

\begin{tabular}{ccccc}
\hline Tahun & $\begin{array}{c}\text { Total Hutang } \\
(\mathrm{T})\end{array}$ & $\begin{array}{c}\text { Ekuitas } \\
(\mathbf{E})\end{array}$ & $\begin{array}{c}\text { Hasil } \\
(\mathrm{T} / \mathrm{E})\end{array}$ & $\begin{array}{c}\text { Standar Rata- } \\
\text { Rata Industri }\end{array}$ \\
\hline 2015 & $\mathbf{1 8 4 . 7 3 0 . 6 5 4 . 2 0 2}$ & $\mathbf{4 5 4 . 5 9 9 . 4 9 6 . 1 7 1}$ & $\mathbf{0 , 4 0}$ & $\mathbf{1 . 1 8}$ \\
\hline 2016 & $\mathbf{2 1 5 . 2 0 9 . 9 0 2 . 8 1 6}$ & $\mathbf{4 7 0 . 6 0 3 . 0 9 3 . 1 7 1}$ & $\mathbf{0 . 4 5}$ & $\mathbf{1 . 0 0}$ \\
\hline 2017 & $\mathbf{2 2 9 . 6 3 0 . 8 5 9 . 7 1 9}$ & $\mathbf{4 5 2 . 3 0 7 . 0 8 8 . 0 1 7}$ & $\mathbf{0 . 5 0}$ & $\mathbf{1 . 0 8}$ \\
\hline
\end{tabular}




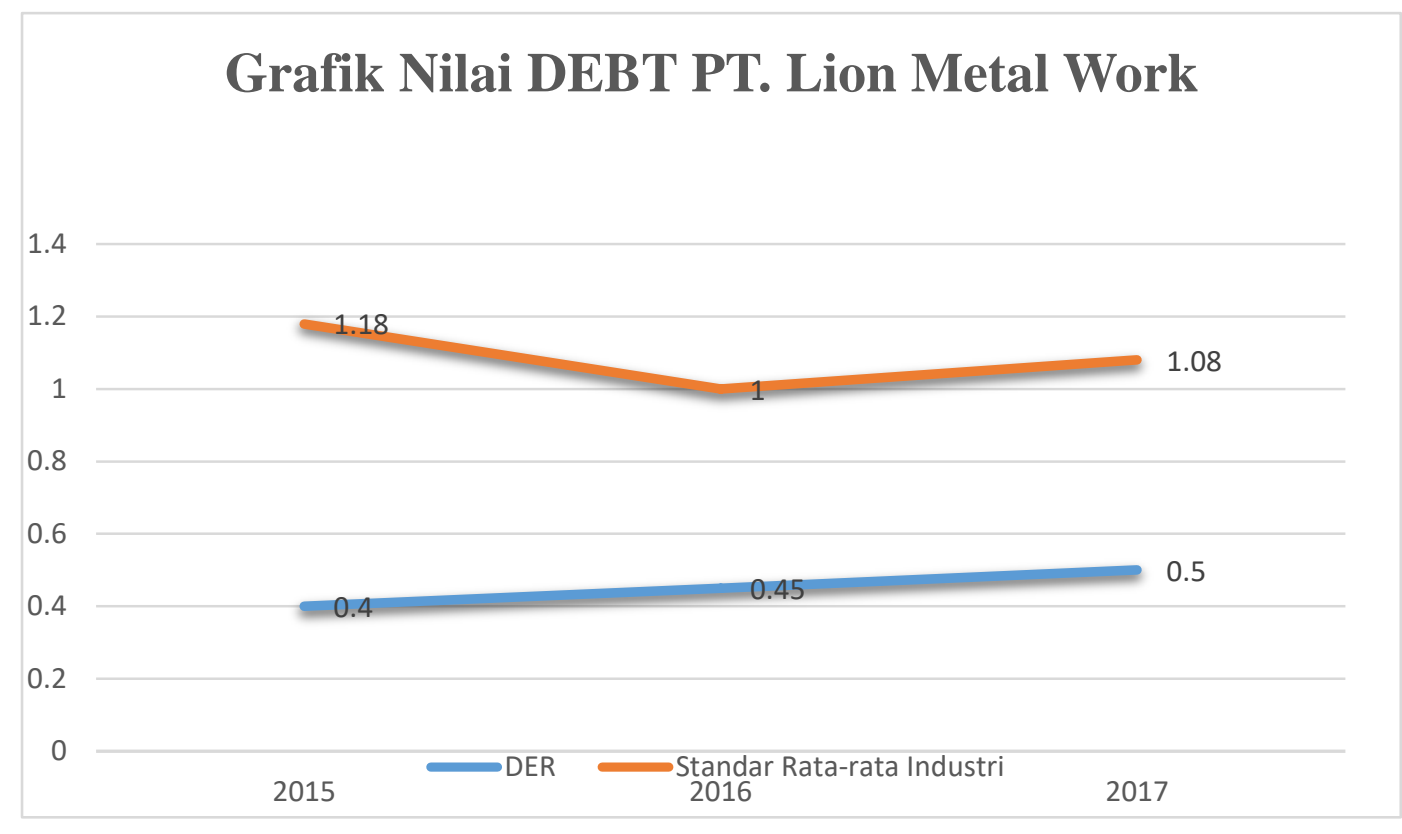

Gambar 3.

Grafik nilai Debt PT. Lion Metal Work

Berdasarkan tabel 8 dan gambar 3 PT. Lion Metal Work mengalami kenaikan hutang, hal ini disebabkan dengan tejadinya kenaikan pada total hutang dari tahun 2015 sampai 2017 sementara hasil dari perolehan nilai debt to equity ratio menunjukan kurang dari standar rata-rata industri, hal ini menunjukkan bahwa perusahaan berada dalam kondisi kurang baik.

\section{Hambatan yang dihadapi perusahaan dalam earning per share antara lain yakni:}

laba perusahaan

Laba perusahaan pada perusahaan setiap tahun mengalami penurunan terutama pada tahun 2017 mengalami penurunan yang cukup dratis sehingga harga saham pun ikut menjadi turun dan para pemegang saham mengalami kerugian. Ketika sebuah perusahaan mengalami penurunan laba maka perusahaan pun bisa mengalami dampak yang sangat buruk yaitu, rasa cemas dan gelisah pada seorang investor akan muncul karena melihat saham perusahaan turun dan akan menarik kembali uang yang telah mereka tanamkan pada perusahaan, kemudian seorang investor yang tadinya akan menanamkan modalnya pada perusahaan, lalu melihat kinerja perusahaan yang menurun maka seorang investor tidak akan jadi menanamkan modalnya pada perusahaan tersebut, karena takut akan mereka merugi saat menanamkan modalnya. 
Total Hutang

Apabila sebuah perusahaan mempunyai hutang yang sangat banyak maka akan mengganggu dari penghasilan keseharian perusahaan sehingga pihak perusahaan tidak bisa mengembalikan hutangnya pada waktu yang sangat cepat.

\section{Penyelesaian Hambatan yang dihadapi perusahaan}

Pihak manajemen perusahaan telah melakukan perbaikan terhadap kinerja perusahaan baik diluar maupun didalam perusahaan, akan tetapi pada kenyataan yang terjadi dilapangan tidak sesuai dengan apa yang diharapkan perusahaan tetap saja laba yang di dapatkan perusahaan dari tahun ketahun pendapatannya tidak meningkat.

Manajemen perusahaan sudah mencoba memperkecil hutang-hutang jangka pendek perusahaan dari mulai hutang pajak dan hutang usaha, tetapi yang terjadi dilapangan dari pendapatan yang tidak meningkat perusahaan tidak dapat memenuhi pengembalian hutang tersebut.

\section{SIMPULAN}

Dari hasil penelitian dan pembahasan maka dapat ditarik kesimpulan yaitu; 1) tingkat pengembalian saham PT. Lion Metal Work Tbk dengan menggunakan metode Earning per Share menunjukan bahwa kondisi pengembalian saham pada tahun 20152016 mengalami kenaikan melebihi dari standar rata-rata industri sedangkan pada tahun 2017 PT. Lion Metal Work mengalami penurunan yang sangat signifikan, yakni tidak memenuhi kriteria standar rata-rata industri yang berarti pengembalian sahamnya kurang baik; 2) pengembalian hutang PT. Lion Metal Work dengan menggunakan metode debt to equity ratio dan dilihat pada standar rata-rata industry dasar dan kimia subsector logam periode 2015-2017 menunjukkan penurunan dan mengalami kenaikan hutang dari tahun ketahun dan posisi nilai ekuitas semakin kecil yang berarti pengembalian hutang dikategorikan kecil atau kurang baik.

\section{DAFTAR PUSTAKA}

Darsono, \& Ashari. (2005). Pedoman Praktik Memahami Laporan Keuangan. Yogyakarta: CV ANDI OFFSET.

Fahmi, I. (2014). Analisis Kinerja keuangan . Bandung: Alfabeta. (2017). Analisis Kinerja keuangan . Bandung: Alfabeta.

Prakoso, R. (2016). Analisis Faktor-Fator yang mempengaruhi Return saham. 
2020. BUDGETING : Journal of Business, Management and Accounting 1 (2):93-108

Samryn. (2012). Akuntansi Manajemen Informasi Biaya Untuk Mengendalikan Aktivitas Operasi dan Informaasi. Jakarta: Prenada Media.

Sudana. (2011). Manajemen Keuangan Perusahaan Teori dan Praktek. Jakarta: Erlangga.

Sugiyono. (2014). Metode penelitian (pendekatan kuantitatif, kualitatif dan R\&D . Bandung: Alfabeta.

Widoatmodjo. (2012). cara sehat investasi di pasar modal edisi Revisi. Jakarta: PT. Jurnalindo Aksara Grafika. 